\title{
Analisis Potensi Legalisasi Eutanasia di Indonesia: Diskursus Antara Hak Hidup dengan Hak Menentukan Pilihan
}

\author{
Xavier Nugraha ${ }^{1}$ \\ Sabdo Adiguno 2 \\ Shintya Yulfa ${ }^{3}$ \\ Yuni Lathifah ${ }^{4}$ \\ ${ }^{1}$ Fakultas Hukum Universitas Airlangga \\ ${ }^{2,3,4}$ Fakultas Hukum Universitas Sebelas Maret \\ Email Korespondensi : nugrahaxavier72@gmail.com
}

\begin{abstract}
The problem of euthanasia has existed since the health community was facing an incurable disease, while the patient was already dying and torturing. In such situations, it is not uncommon for patients to beg for relief from this suffering and do not wish to have their life extended. This is where the term euthanasia appears, which is letting go of one's life in order to be free from suffering or to die properly. This study aims to determine the concept of freedom to live, human freedom to choose and review legal norms in Indonesia and several other countries. However, in its application there is a dilemma, which is considered contrary to the right to life if euthanasia is carried out. This research is a legal research with an approach obtained by examining library materials or secondary data or what is called normative legal research or literature law research. The approach in research uses aConceptual Approach, which is an approach that departs from the views or doctrines that develop in legal science to build legal arguments when solving legal issues at hand. From this legal research study, it can be concluded that the presence of euthanasia is considered a human right in the form of the right to die which is considered to bring happiness and pleasure to him. Eutanasia when viewed from the aspect of criminal law and human rights in Indonesia are still having a debate that has not found the end, for the provision of human rights by the opposition national laws, especially the Criminal Code so there needs to be development of the law on regulation of euthanasia in Indonesia by taking into account medical factors normative.
\end{abstract}

Keywords: Euthanasia; Human rights; Legalization

\begin{abstract}
ABSTRAK
Permasalahan eutanasia sudah ada sejak kalangan kesehatan menghadapi penyakit yang tak tersembuhkan, sementara pasien sudah dalam keadaan sekarat dan menyiksa. Dalam situasi demikian, tidak jarang pasien memohon agar dibebaskan dari penderitaan ini dan tidak ingin diperpanjang hidupnya. Dari sinilah istilah eutanasia muncul, yaitu melepas kehidupan seseorang agar terbebas dari penderitaan atau mati secara baik. Penelitian ini bertujuan untuk mengetahui konsep kebebasan untuk hidup, kebebasan manusia untuk memilih dan meninjau norma hukum di Indonesia serta beberapa Negara lain. Akan tetapi dalam penerapannya terdapat dilematika, dimana dianggap bertentangan dengan hak hidup jika euthanasia dilakukan. Penelitian ini adalah penelitian hukum dengan pendekatan yang diperoleh dengan cara meneliti bahan pustaka atau data sekunder atau disebut dengan penelitian hukum normatif atau penelitian hukum kepustakaan. Pendekatan dalam penelitian menggunakan Pendekatan Konseptual dan Pendekatan Peraturan Perundang-undangan untuk menyelesaikan
\end{abstract}


isu hukum yang dihadapi. Dari kajian penelitian hukum ini dapat di simpulkan bahwa hadirnya eutanasia dianggap sebagai hak asasi manusia berupa hak untuk mati yang dianggap dapat mendatangkan kebahagiaan dan menyenangkan bagi dirinya. Eutanasia jika ditinjau dari aspek hukum pidana dan hak asasi manusia di Indonesia masih mengalami perdebatan yang belum menemukan ujung, karena antara pemberian hak asasi manusia dengan pertentangan hukum nasional khususnya KUHP sehingga perlu ada perkembangan hukum terhadap pengaturan eutanasia di Indonesia dengan memperhatikan faktor medis normatif.

Kata Kunci: Eutanasia; Hak Asasi Manusia; Legalisasi

\section{Pendahuluan}

Eutanasia hingga hari ini masih menjadi topik yang kontroversial di bidang kesehatan, hukum, dan hak asasi manusia. ${ }^{1} \mathrm{~J}$ Scherer dan R Simon menyebut terdapat tiga isu global yang mendorong pentingnya diskursus mengenai eutanasia, yakni: (1) Perkembangan teknologi di bidang kedokteran yang memperpanjang kemungkinan hidup pasien; (2) Fenomena meningkatnya populasi dengan usia lanjut dan banyaknya jumlah orang yang terkena HIV/AIDS; dan (3) Melemahnya pengaruh dari institusi keagamaan. Eutanasia sendiri berasal dari Bahasa Yunani yang memiliki arti "mati secara baik dan mudah", yang dapat diartikan tindakan dari seseorang ingin mati dengan kondisi bahwa kematian menjadi hal yang tidak menimbulkan penderitaan untuknya. ${ }^{2}$ Dalam perkembangannya, pengertian eutanasia kemudian diperluas dan ditambahkan unsurnya menjadi: “......dan sebagai cara menangani korban-korban yang mengalami sakit yang tidak mungkin disembuhkan lagi"”.

Pada titik ini juga timbul pertanyaan mengenai bilamana sebuah penderitaan pasien harus diakhiri, karena penderitaan sendiri bersifat subyektif dan sulit untuk menetapkan tolok ukurnya secara obyektif. Dengan dasar tersebut, penilaian mengenai pasien menderita atau tidak diproyeksikan pada diri dokter sebagai penilai. Namun dilema selanjutnya adalah proyeksi sang penilai bergantung pada kadar empatinya dan pengalamannya. Penafsiran terhadap penderitaan seorang pasien akan bertambah rumit karena melibatkan keluarga yang juga terbebani oleh faktor ekonomi, terkurasnya waktu, tenaga, dan pikiran.

Apabila kita sepakat bahwa penilaian perihal penderitaan pasien lebih baik diserahkan pada dokter yang benar-benar memahami pasien dan penyakitnya, pertanyaan yang timbul berikutnya adalah: "Bagaimana posisi dokter jika ada kasus penyakit yang tidak dapat

\footnotetext{
${ }^{1}$ Pingkan K. Paulus. (2013). "Kajian Euthanasia Menurut HAM (Studi Banding Hukum Nasional Belanda)," Jurnal Hukum Unsrat, 21(3).

${ }^{2}$ Nuno Ferreira. (2005). "Revisiting Euthanasia: A Comparative Analysis of a Right to Die in Dignity," SSRN Electronic Journal, 4(8): 1-66.

${ }^{3}$ Abd Halim. (2012) "Euthanasia Dalam Perspektif Moral Dan Hukum," Jurnal Pemikiran Hukum Al-Mazaib, 1(4): $1-13$
} 
disembuhkan atau pasien menderita sakit terus menerus?" atau mungkin kita bertanya-tanya: "Mana yang lebih baik antara membiarkan pasien terus tersiksa oleh penyakitnya atau mempercepat kematiannya?" Dalam Pasal 9 bab II Kode Etik Kedokteran Indonesia tentang kewajiban kedokteran kepada pasien, disebutkan bahwa:" Seorang dokter senantiasa mengingat akan melindungi hidup makhluk insani”. Namun berbeda dengan pendapat seorang filsuf abad ke-17 yang bernama Francis Bacon dalam bukunya yang berjudul "Novum Organum", berpendapat bahwa tugas seorang dokter bukan hanya menyembuhkan pasien, tapi juga memperbolehkan pasien untuk mati dengan cara yang mudah dan tenang. ${ }^{4}$ Tentu disini akan menjadi dilema bagi seorang dokter untuk menyelamatkan nyawa pasien namun tidak semua penyakit dapat disembuhkan olehnya.

Ketika eutanasia diperbincangkan menjadi jamak untuk membaginya menjadi dua kategori, yakni 1) eutanasia aktif dan 2) euthanasia pasif. Eutanasia aktif dapat diartikan sebagai kehendak yang bersangkutan meminta agar hidupnya diakhiri dengan segera dan dokter atau orang lain mengambil tindakan-tidakan untuk mempercepat kematian orang tersebut, ${ }^{5}$ sedangkan eutanasia pasif dapat diartikan bila orang yang bersangkutan menghendaki segala usaha pertolongan untuk memperpanjang hidupnya dihentikan sehingga maut bisa segera menjemputnya karena sudah tidak dapat menahan penderitaan yang berkepanjangan. ${ }^{6}$ Jika dihubungkan dengan hukum positif Indonesia, terutama ketentuan Pasal 345 KUHP yang melarang setiap orang untuk mendorong, menolong, dan memberi sarana kepada orang lain untuk bunuh diri, maka dokter maupun orang yang membantu pasien melakukan eutanasia aktif dapat dipidana dengan pasal tersebut. Namun apakah eutanasia pasif kemudian menjadi lebih bermoral atau sah menurut hukum dibandingkan eutanasia aktif? Mengingat tidak ada ancaman pidana bagi eutanasia pasif.

Meskipun secara yuridis eutanasia masih belum dimungkinkan, ternyata permohonan untuk eutanasia aktif pernah diajukan oleh beberapa orang dalam beberapa tahun ini. Salah satunya oleh Berlin Silalahi yang mengajukan permohonan eutanasia aktif atau suntik mati kepada Pengadilan Negeri Banda Aceh, lantaran kondisinya lumpuh dan mengalami penyakit kronis. ${ }^{7}$ Isu tersebut sudah selayaknya diangkat kembali untuk merespon kejadian serupa di tempat lain dan bagaimana untuk memecahkan permasalahan kronis yang menimpa individu.

\footnotetext{
${ }^{4}$ Nuno Ferreira, loc.cit.

${ }^{5}$ Abd. Halim, loc.cit.

${ }^{6}$ Ibid.

${ }^{7}$ Yantina Debora, 2017, Permintaan Suntik Mati Yang Kotroversial, https://tirto.id/permintaan-suntik-matiyang-kontroversial-cokd, diakses pada 13 November 2020.
} 
Berdasarkan definisi eutanasia aktif dan pasif di atas sebetulnya pasien ingin mengakhiri penderitaan atas rasa sakitnya, namun hanya cara untuk mengakhiri hidupnya saja yang berbeda. Menurut Nuno Ferreira, klasifikasi di atas menjadi tidak relevan jika membincangkan topik mengenai legalisasi eutanasia karena kurang signifikan perbedaannya, maka dari itu diperlukan kategori yang cenderung bebas nilai dan moral dengan kriteria Voluntary dan Non-Voluntary Euthanasia. ${ }^{8}$ Voluntary Euthanasia diartikan sebagai tindakan seseorang yang membantu mengakhiri hidup orang yang menderita penyakit berdasarkan permintaan atau keinginan, sedangkan Non-Voluntary Euthanasia ada ketika kondisi pasien karena penyakitnya tidak dapat mengekspresikan kehendaknya untuk hidup atau mati. ${ }^{9}$ Berdasarkan hal tersebut, maka dapat dipahami, bahwa perbedaan antara eutanasia voluntary dan non-voluntary terletak pada apakah pasien bisa menyatakan kehendaknya atau tidak.

Menanggapi perbedaan kategori eutanasia di atas, Penulis ingin menggunakan kategorisasi yang memadukan eutanasia aktif dan pasif serta voluntary dan non-voluntary euthanasia sebagaimana yang diajukan oleh Natasha Cica. Terdapat empat kategori euthanasia, diantaranya. ${ }^{10}:$ (1) Passive voluntary euthanasia: kondisi ketika perawatan medis terhadap pasien dihentikan atau ditangguhkan berdasarkan permintaan pasien sendiri dan bermaksud untuk mengakhiri hidup dari pasien secara perlahan; (2) Active voluntary euthanasia: ketika intervensi sarana medis berperan untuk mengakhiri hidup pasien berdasarkan permintaannya sendiri; (3) Passive involuntary euthanasia: perawatan medis terhadap pasien dihentikan atau ditangguhkan dan bermaksud untuk mengakhiri hidup dari pasien secara perlahan, namun bukan berasal dari permintaan pasien tersebut; (4) Active involuntary euthanasia: ketika intervensi sarana medis berperan untuk mengakhiri hidup pasien namun tidak berdasarkan permintaannya sendiri.

Melihat permasalahan hukum di atas, maka Penulis tertarik untuk mengkaji isu mengenai kemungkinan legalisasi eutanasia di Indonesia. Dalam tulisan ini legalisasi eutanasia yang dimaksud adalah kategori active voluntary euthanasia. Terdapat dua argumentasi yang melandasi mengapa Penulis ingin membatasi lingkup legalisasi eutanasia, yakni: Active voluntary euthanasia memiliki persinggungan dengan isu kebebasan individu untuk memilih atau option luck. Untuk keperluan praktis, yakni memadatkan pembahasan

\footnotetext{
${ }^{8}$ Nuno Ferreira, loc.cit.

${ }^{9}$ Agarwal Ritu and Balyan Bhavya. (2019). "Euthanasia: An Indian Perspective," ZENITH International Journal of Multidisciplinary Research 9(6):367-373.

10 Cica Natasha. (1996) ."Euthanasia- the Australian Law in an International Context Part I: Passive VoluntaryEuthanasia Research Paper.” Parliamentary Library Research Paper.
} 
tulisan ini, argumentasi yang dipergunakan untuk legalisasi involuntary euthanasia memerlukan pemaparan yang sama panjangnya dengan active voluntary euthanasia.

Penulis akan mengkaji seberapa jauh konsep hak manusia untuk hidup. Kemudian Penulis akan menjabarkan mengenai kebebasan manusia untuk menentukan pilihan atau option luck yang notabene akan disinggung pula mengenai hak untuk tidak disiksa atau right to freedom from cruel dan kebebasan untuk meyakini kepercayaan, menyatakan pikiran dan sikap sesuai dengan hati nuraninya. Sub bahasan berikutnya yang disajikan Penulis adalah perbandingan legalisasi euthanasia di negara lain dan dilengkapi dengan mekanisme kongkrit pelaksanaan eutanasia apabila dilegalisasi di Indonesia.

Menilik dari latar belakang yang telah dipaparkan di atas, penulis menyusun suatu perumusan masalah sebagai pertanyaan dasar yang akan dikaji dalam penelitian hukum ini, yakni: Pertama, Bagaimana konsep hak untuk hidup dan hubungannya dengan eutanasia serta kebebasan manusia untuk menentukan pilihan? dan Kedua, Bagaimana potensi legalisasi euthanasia di Indonesia dan beberapa negara lain? Adapun tujuan dari penelitian ini adalah Pertama, menganalisis dan menemukan konsep hak untuk hidup dan hubungannya dengan eutanasia serta kebebasan manusia untuk menentukan pilihan dan Kedua, menganalisis potensi legalisasi euthanasia di Indonesia.

\section{Metode Penelitian}

Penelitian ini merupakan penelitian hukum yang notabene menganalisis isu hukum yang ada dengan ciri utama menggunakan argumentasi hukum untuk menganalisis isu hukum tersebut. ${ }^{11}$ Jenis peneltian yang dilakukan adalah penelitian hukum doktrinal. Penelitian ini berusaha memberikan penjelasan sistematis tentang peraturan tertentu, menganalisis hubungan antar aturan, menjelaskan permasalahan, dan mungkin memprediksi pembangunan hukum masa depan. ${ }^{12}$ Penelitian ini termasuk dalam jenis penelitian preskriptif. Pendekatan yang digunakan dalam pendekatan ini adalah pendekatan undang-undang (statute approach) dan pendekatan konseptual (conceptual approach). Jenis data yang digunakan adalah: (1) Data primer, yaitu data yang diperoleh dari perundang- undangan. Adapun peraturan perundang-undangan yang digunakan adalah Kitab UUD NRI 1945 dan Kitab UndangUndang Hukum Pidana (KUHP); (2) Data sekunder, yaitu data yang diperoleh dari bahan pustaka, antara lain buku-buku, literatur ilmiah, jurnal hukum maupun ilmu lainnya, serta

\footnotetext{
11 Xavier Nugraha, Risdiana Izzaty, and Annida Aqiila Putri. (2019). "Rekonstruksi Batas Usia Minimal Perkawinan Sebagai Bentuk Perlindungan Hukum” 3(1): 40-54.

${ }^{12}$ Peter Mahmud Marzuki. (2005). Penelitian Hukum. Jakarta: Kencana Prenada Media Group.
} 
sumber lainnya yang terkait dengan penelitian ini, seperti Artikel dari Pingkan K. Paulus dengan judul"Kajian Euthanasia Menurut HAM (Studi Banding Hukum Nasional Belanda)," Jurnal Hukum Unsrat 21, no. 3 (2013), artikel dari Nuno Ferreira, berjudul "Revisiting Euthanasia: A Comparative Analysis of a Right to Die in Dignity," SSRN Electronic Journal 4, no. 8 (2005), artikel dari Abd Halim, dengan judul "Euthanasia Dalam Perspektif Moral Dan Hukum," Jurnal Pemikiran Hukum Al-Mazaib 1 (2012), dan sebagainya; dan (3) Data tersier, yaitu data yang diperoleh dari kamus hukum dan surat kabar cetak maupun daring, misal artikel dari Yantina Debora dengan judul Permintaan Suntik Mati yang Kontroversial yang diakses di https://tirto.id/permintaan-suntik-mati-yang-kontroversial-cokd. ${ }^{13}$ Data-data hukum yang diperoleh akan dianalisis dengan menggunakan teknik analisis logika deduktif.

\section{Analisis dan Pembahasan}

\section{Konsep Hak untuk Hidup dan Hubungannya dengan Euthanasia}

Hak untuk hidup atau freedom of life disebutkan secara eksplisit dalam Article 6 (1) International Covenant on Civil and Political Rights (ICCPR)sebagai berikut: "Every human being has the inherent right to life. This right shall be protected by law. No one shall be arbitrarily deprived of his life." Hak untuk hidup dikategorikan sebagai "supreme human right" karena tanpa jaminan perlindungan yang efektif, membuat hak-hak yang lain tanpa arti. ${ }^{14}$ Diperkuat pula dengan pendapat Dinstein sebagaimana dikutip George Zdenkowski, bahwa hak untuk hidup adalah hak paling mendasar dalam masyarakat yang beradab. ${ }^{15}$ Hanya hak inilah yang disebutkan secara eksplisit sebagai "inherent" atau melekat dengan kemanusiaan. ${ }^{16}$ Kemudian kalimat kedua Article 6(1) di atas menghendaki sebuah kewajiban bagi negara untuk berperan melindungi hak untuk hidup.

Hak untuk hidup yang tidak boleh dicabut secara semena-mena oleh individu lain maupun oleh negara atau "arbitrarily deprived" yang dilaksanakan dengan membatasi cakupan dari hak tersebut, dan oleh karena itu merupakan tugas negara untuk memastikan hak untuk hidup. Cakupan dari hak untuk hidup sendiri menurut Dinstein sebagaimana dikutip George Zdenkowski adalah hak untuk dilindungi dari hukuman mati yang semena-

\footnotetext{
${ }^{13}$ Soerjono Soekanto and Sri Mahmudi. (1986). Penelitian Hukum Normatif Suatu Tinjauan Singkat. Jakarta: PT Grafindo Persada.

${ }^{14}$ Manfred Nowak. (2005). U.N. Covenant on Civil and Political Rights : CCPR Commentary. Germany: Arlington, Va., U.S.A. : N.P. Enge,.

15 George Zdenkowski. (2015). "Human Rights and Euthanasia," Deutsches Zentralblatt fur Krankenpflege 11(1).

${ }^{16}$ Manfred Nowak, loc.cit.
} 
mena. ${ }^{17}$ Dalam proses pembentukan Article 6(1) ICCPR sendiri, beberapa perwakilan negara-negara dengan tradisi hukum Anglo-Saxon mempersamakan makna "arbitrarily" dengan "without due process of law" atau tanpa prosedur hukum yang jelas. ${ }^{18}$ Dengan demikian hak untuk hidup memiliki cakupan yang terpisah dengan misalnya kegagalan pemerintah untuk memenuhi gizi bayi yang kemudian mengakibatkan tingginya angka kematian untuk bayi.

BG Ramcharan sebagaimana juga dikutip oleh George Zdenkowski berpendapat bahwa pemilihan kata "arbitrarily" didasarkan pada perlindungan atas hak untuk hidup yang bisa dilakukan oleh negara semaksimal mungkin dan untuk membatasi seminimal mungkin tindakan yang diperbolehkan untuk merampas hak untuk hidup. Sehingga ada dua faktor yang dapat membantu kita untuk menentukan apakah sebuah perampasan hak untuk hidup dikatakan "arbitrarily" atau tidak, yakni pengawasan hukuman secara ketat dan proporsionalitas. ${ }^{19}$ Ramcharan berkesimpulan bahwa hak untuk hidup adalah norma yang mengikat dalam hukum internasional, namun hak tersebut tidaklah absolut. ${ }^{20}$

Konteks yang sama dapat dipahami dalam hukum nasional Indonesia. Pasal 28A UUD NRI 1945 menjamin setiap orang berhak untuk hidup serta mempertahankan kehidupannya. Anatomi pasal-pasal tentang Hak Asasi Manusia dalam konstitusi diikuti dengan keberadaan Pasal 28J ayat (2), konsekuensi logis dari hal tersebut adalah setiap hak yang dijamin dalam UUD NRI 1945 dapat dibatasi oleh undang-undang dengan maksud: (1) Menjamin pengakuan dan penghormatan atas hak dan kebebasan orang lain; dan (2) Memenuhi tuntutan yang adil sesuai dengan pertimbangan moral, nilai-nilai agama, keamanan, dan ketertiban umum dalam suatu masyarakat yang demokratis. Pemaknaan Article 6(1) yang menjamin hak untuk hidup oleh MK cenderung partikularistik, seperti dalam Putusan MK Nomor 2-3/PUU-V/2007 yang menguji konstitusionalitas hukuman mati dalam UU Nomor 22 Tahun 1997 tentang Narkotika. Meskipun mengakui semangat dari ICCPR adalah untuk menghapus hukuman mati, namun MK berpendapat bahwa hukuman mati masih bisa dijatuhkan untuk kejahatan-kejahatan paling serius atau the most serious crime. $^{21}$ Dalam ratio decedendi putusan tersebut, MK berpendapat bahwa

\footnotetext{
${ }^{17}$ George Zdenkowski, loc.cit.

${ }^{18}$ Ibid.

${ }^{19}$ Ibid.

${ }^{20}$ Ibid.

21 Pan Mohamad Faiz. (2015). "Pendekatan MK Terhadap Konstitusionalitas Hukuman Mati," Majalah Konstitusi No. 96.
} 
narkotika termasuk dalam kejahatan serius karena bisa memengaruhi pondasi ekonomi, politik, dan budaya dalam masyarakat. ${ }^{22}$

Bahwa sejatinya, jika dianalisis tidak ada relasi antara hak untuk hidup yang harus dilindungi negara dengan eutanasia. Berikut adalah Komentar UN Human Right Committee berikut menyatakan bahwa hukum yang melegalkan voluntary euthanasia tidak berhubungan dengan kewajiban negara untuk melindungi hak untuk hidup: ${ }^{23}$

"If a national legislature limits criminal responsibility here after carefully weighing all the affected rights and takes adequate precautions against potential abuse, this is within the scope of the legislature's discretion in carrying out its duty to ensure the right...the State's obligation to ensure does not go so far as to require that life and health be protected against the express wishes of those affected"

Dari pernyataan di atas, komentar UN Human Rights Committee menunjukkan bahwa hukum negara yang memperbolehkan eutanasia harus menyediakan prosedur keselamatan yang efektif akan bahaya penyalahgunaan. ${ }^{24}$ Artinya perlu prosedur operasional yang menjadi panduan bagi dokter dalam melakukan eutanasia berdasarkan permintaan pasien.

\section{Kebebasan Manusia untuk Menentukan Pilihan}

Hak untuk hidup merupakan suatu hak asasi manusia dan melekat dalam diri manusia, namun bagaimana dengan hak untuk mati? Selain hak hidup manusia memiliki hak asasi yang berkaitan dengan hak menentukan diri sendiri. Berawal dari sini kemudian lahirlah pemikiran adanya eutanasia secara sukarela, dimana hak untuk mati dianggap jugabagian dari hak asasi manusia. Kepemilikan hak ini sering dikaitkan dengan orang yang mengalami sakit sudah mencapai tahap terminal dan diizinkan untuk menyudahi hidupnya, atau meminta bantuan demi mengakhiri nyawanya atau menolak untuk menjalankan perawatan demi memperpanjang kehidupannya.

Hadirnya eutanasia dianggap sebagai hak asasi manusia berupa hak untuk mati yang dianggap dapat mendatangkan kebahagiaan dan menyenangkan bagi dirinya. Hak asasi manusia berupa hak untuk mati dianggap suatu konsekuensi dari hak untuk hidup. Oleh karena terdapat hak untuk hidup maka setiap orang juga berhak untuk memiliki hak untuk mati yang kemudian disebut dengan eutanasia.

\footnotetext{
${ }^{22}$ Xavier Nugraha et al.. (2020). “Analisis Penerapan Asas Safety Beyond Economic Reason Dalam Putusan Mahkamah Konstitusi Nomor 41/PUU-XVI/2018," Humani (Hukum dan Masyarakat Madani), 10(2): $216-228$.

${ }^{23}$ Philip Baker. (2016). "Human Rights and the Law," Australian Human Rights Commission, 6(3): 26-27.

24 Ibid.
} 
Demi menentukan hak-hak yang akan diperoleh maka pilihan hidup oleh seseorang tidak dapat diabaikan. Ketika eutanasia dianggap bisa mencapai kematian yang menyenangkan bagi pasien artinya, pilihan mati merupakan wujud dari pilihan akhir dari kehidupan yang tidak bisa diabaikan. Akan tetapi jika keputusan yang diambil mendatangkan ketidakberuntungan, kompensasi tidak diberikan bagi individu yang telah memilih bagi kehidupannya sendiri. Terdapat perbedaan antara option luck dan brute luck menurut Ronal Dworkin. Adapun yang dimaksud dengan Option luck merupakan kondisikondisi yang bisa terjadi sebab keputusan terbut dari pilihan yang kita buat. Sementara brute luck yaitu kondisi-kondisi yang bisa terjadi numun bukan dari pilihan atau keputusan yang kita buat. $^{25}$ Hal yang wajar apabila kompensasi diberikan kepada orang yang mengalami ketidakberuntungan karena kondisi yang dialami bukan karena pilihan dari orang tersebut. Misalnya, ketika seorang pasien mengalami sakit parah tumor otak dan kecil kemungkinannya untuk sembuh kemudian pasien tersebut mengingkan eutanasia yang diyakininya bisa memberika kematian yang menyenangkan, hal ini menjadi wajar dilakukan karena dalam keadaan sakit parah (ketidak beruntungan) yang dialami bukan merupakan pilihan hidupnya, maka keputusan untuk memilih mati menjadi adalah hal wajar untuk dilakukan.

Hak untuk hidup bukanlah hak mutlak, oleh Karena itu, istilah "hak fundamental" tidak boleh menyembunyikan fakta bahwa ia adalah hak yang sangat rapuh dan sangat rentan terhadap interpretasi berbasis kepentingan. ${ }^{26}$ Jika di kaji lebih dalam sebenarnya manusia tidak memiliki hak untuk hidup karena secara filosofis manusia ada dan hidup karena kehendak Tuhan Yang Maha Esa. ${ }^{27}$ Manusia sebenarnya tidak memiliki hak untuk hidup atas dirinya karena manusia tidak memiliki hidup itu sendiri. Hal ini bisa dilihat dari kelahiran manusia, ia tidak memiliki hak kapan dia ingin dilahirkan, dalam keadaan kondisi yang seperti apa ia lahir, dan juga dari Rahim siapa dilahirkan. Jika hak hidup berada ditangan manusia maka dia dapat memilih kapan dia lahir dan dalam keadaan seperti apa dia hidup. Akan tetapi pada kenyataannya manusia tidak memiliki hak yang demikian. Manusia hanya sebatas mengetahui ia telah lahir dan dikaruniai kehidupan.

\footnotetext{
${ }^{25}$ Ronald Dworkin. (2000). Sovereign Virtue The Theory and Practice of Equality. Cambridge, Massachusetts: Harvard University Press.

${ }^{26}$ Hans-Georg Ziebertz and Francesco Zaccaria. (2018). Euthanasia, Abortion, Death Penalty and Religion: The Right to Life and Its Limitations: International Empirical Research. Switzerland: Springer Nature Switzerland AG.

${ }^{27}$ Nur Hayati. (2004). "Euthanasia Dalam Perspektif Hak Asasi Manusia Dan Kaitannya Dengan Hukum Pidana," Lex Jurnalica, 1(2): 90-99.
} 
Dari penjelasan di atas, kehidupan manusia sepenuhnya milik Tuhan Yang Maha Esa, sehingga manusia tidak memiliki hak untuk hidup ataupun hak untuk mati. Karena Tuhan telah memberikan karunia kehidupan kepadanya, sehingga ia memiliki hak untuk mempertahankan hidupnya. Jadi lebih tepatnya manusia memiliki hak untuk mempertahankan hidup bukan hak untuk hidup. Dari hak mempertahankan hidup lahirlah hak untuk mendapatkan perlakuan yang sama, hak untuk merdeka dan hak untuk kebebasan bergerak. Menurut J. A. Van der Ven ${ }^{28}$ :

religious point of view, the dignity of every human life derives from this belief that it is given by God, and therefore it has to be accepted, cherished and protected, and not violated or terminated."

Hal ini menyebabkan bila berbicara pandangan dari dunia agama dalam hal perlindungan hak untuk hidup sangat sensitif, dan mereka tidak mudah dalam hal membenarkan mengahiri kehidupan. Dari uraian diatas dapat disimpulkan bahwa hak untuk mati merupakan sebuah perkembangan dari hak asasi manusia tentang hak untuk hidup.

Apabila dikaji lebih dalam, maka hak untuk mati bukanlah suatu perkembangan dari adanya hak untuk hidup karena kematian dan kehidupan tidak berbanding lurus, tetapi berbanding terbalik. Kehidupan tidak dapat dimiliki bersamaan dengan kematian. Kehidupan dan kematian selalu berada pada posisi yang bersebrangan dimana jika tidak hidup maka berarti mati, dan sebaliknya. Dalam hal ini, karena hidup dan mati adalah dua hal yang berlawanan, maka tidak mungkin jika hak untuk mati merupakan perkembangan dari hak untuk hidup. ${ }^{29}$

Pandangan baru tentang konsep hak untuk mati terasa sangat ganjil sehingga menimbulkan banyak pro dan kontra, karena dianggap tercakup pengertiannya dalam hak untuk hidup yang selama ini telah diketahui secara jelas. Tidak tercantum secara jelas hak untuk mati bagi seseorang, terkait dengan mati sepertinya lebih cenderung melakukan pelanggaran hak untuk hidup.

Membicarakan eutanasia $(e u=\text { baik, thanatos }=\text { mati, mayat })^{30}$, sebenarnya tidak lepas dari apa yang disebut hak untuk menentukan nasib sendiri (the right self of determination) pada diri pasien. Hak untuk menentukan nasib sendiri dalam praktek eutanasia menjadi suatu titik fokus sendiri apakah itu melanggar hak asasi manusia atau

\footnotetext{
${ }^{28}$ J. A. Van der Ven. (2010). Human Rights or Religious Rules?. Leiden/Boston: Brill.

${ }^{29}$ Nur Hayati, loc.cit.

${ }^{30}$ Pingkan K. Paulus, loc.cit.
} 
tidak. ${ }^{31}$ Dalam kasus eutanasia, dibedakan apakah bantuan aktif atau bantuan pasif yang diberikan. Bantuan aktif sangat kontroversial dan umumnya dilarang, bahkan dalam bantuan pasif sejumlah kriteria dibahas mengenai kapan dan dalam keadaan seperti apa bantuan tersebut diizinkan. ${ }^{32}$ Eutanasia aktif bisa dilakukan dengan cara menyuntikkan suatu senyawa yang mematikan atau diberikan melalui oral ke dalam tubuh seseorang, salah satu contohnya adalah tablet sianida. Sementara euthanasia yang pasif dengan cara tidak memberikan perawatan atau menghentikan alat bantu yang dapat membantu pasien memperpanjang hidup pasien secara sengaja, misalnya dengan tidak memberikan oksigen pada pasien yang mengalami kesulitan bernafas, meniadakan operasi yang jika dilakukan seharusnya bisa membantu untuk memperpanjang hidup pasien, ataupun memberikan obat penghilang rasa sakit yang tanpa disadari ini bisa mengakibatkan kematian.

Hak untuk menentukan nasib sendiri merupakan bagian dari Hak Asasi Manusia, pada hakekatnya hak ini menjadi bagian bagi hak-hak dasar tertentu, termasuk dalam hal ini hak dari pasien untuk menentukan pilihannya dalam hal pelayanan kesehatannya. ${ }^{33}$ Kemudian pada akhirnya hak ini yang dikaitkan dengan seorang pasien yang ingin mengakhiri kehidupannya dengan cara eutanasia. Hal ini di dasarkan pada hak dari pasien itu sendiri dalam menentukan kehidupannya.

\section{Kemungkinan Legalisasi Euthanasia \& Perbandingan dengan Negara Lain}

\section{1) Aturan Norma Hukum Euthanasia di Indonesia}

Pengaturan eutanasia di dalam hukum positif Indonesia secara khusus belum ditemukan dalam undang - undang kesehatan, undang - undang rumah sakit dan undang-undang praktik kedokteran. ${ }^{34}$ Di Indonesia, secara yuridis hanya dikenal dua bentuk eutanasia, yaitu eutanasia yang dilakukan atas permintaan pasien / korban itu sendiri dan eutanasia yang dilakukan dengan sengaja membiarkan pasien / korban sebagaimana secara eksplisit diatur dalam Pasal 344 KUHP dan Pasal 304 KUHP. ${ }^{35}$ Pasal 304 KUHP menyatakan : "Barangsiapa dengan sengaja menempatkan atau membiarkan seseorang dalam keadaan sengsara, padahal menurut hukum yang berlaku baginya atau karena persetujuan dia wajib memberi kehidupan, perawatan atau

\footnotetext{
31 Ibid.

${ }^{32}$ Hans-Georg Ziebertz and Francesco Zaccaria, loc.cit.

${ }^{33}$ Pingkan K. Paulus, loc.cit.

${ }^{34}$ Ni Gusti Ayu Agung Febri Dhamayanti and Made Nurmawati. (2019). “Tinjauan Yuridis Euthanasia Ditinjau Dari Aspek Hukum Pidana," Jurnal Kertha Wicara, 8(10): 1-13.

${ }^{35}$ Tjandra Sridjaja Pradjonggo. (2016). "Suntik Mati (Euthanasia) Ditinjau Dari Aspek Hukum Pidana Dan Hak Asasi Manusia Di Indonesia,” Jurnal Ilmiah Pendidikan Pancasila dan Kewarganegaraan, 1(1) :56-63.
} 
pemeliharaan kepada orang itu, diancam dengan pidana penjara paling lama dua tahun delapan bulan atau pidana denda paling banyak empat ribu lima ratus rupiah."

Sementara pasal 344 KUHP secara tegas menyatakan: "Barang siapa merampas nyawa orang lain atas permintaan itu sendiri yang jelas dinyatakan dengan kesungguhan hati diancam dengan pidana penjara paling lama dua belas tahun”. Dengan demikian, dalam konteks hukum positif di Indonesia, "pengakhiran hidup seseorang" merupakan sesuatu yang dilarang sekalipun atas permintaan orang itu sendiri karena perbuatan tersebut, dikualifikasi sebagai tindak pidana. Dalam hal ini, bentuk merampas nyawa orang lain yang diatur pada Pasal 344 KUHP ini adalah bentuk dari eutanasia aktif (atas permintaan) langsung.

Patut dicermati bahwa pasal 344 KUHP tersebut terdapat kata "atas permintaan sendiri" yang disertai pula dengan kalimat "yang jelas dinyatakan dengan kesungguhan hati" menyebabkan perumusan Pasal 344 KUHP menimbulkan kesulitan dalam pembuktiannya pada saat di persidangan. ${ }^{36}$ Sebagai contoh misalnya di suatu kondisi seorang pasien dalam keadaan sakit yang parah dan tidak memiliki kemampuan untuk berkomunikasi dalam bentuk apapun sehingga tidak dapat menyatakan dengan kesungguhan hati terhadap keinginannya mengakhiri hidup. Eutanasia kerap terjadi pada pasien dengan keadaan kritis dengan kondisi diatara mati tidak dan hidup pun juga tidak (in persistent vegetative state). ${ }^{37}$ Tentunya hal ini akan membawa konsekuensi hukum pada dokter yang bertanggungjawab melakukan tindakan.

Contoh lain adalah pasien dengan penyakit kanker yang cenderung tidak dapat tertolong. Pasien kanker tersebut akan merasakan nyeri yang tidak tertahankan dan penderitaan yang luar biasa, atau pasien yang berada dalam in persistent vegetative state menyebabkan dilema sang dokter untuk melakukan tindakan medis yang akan dilakukan. Tentunya dokter - dokter yang bertanggungjawab akan mengalami pertentangan batin yang dilematis terhadap pasien yang bersangkutan karena tindakan medis yang akan dilakukan berdampak pada aspek hukum, moral dan etika serta berimplikasi medis. Maka dari itu, ketika melihat implikasi hukum dalam tindakan eutanasia ini dari sisi hukum pidana khususnya yang diatur dalam KUHP, patut menjadi bahan pertimbangan apakah perbuatan yang dilakukan itu termasuk suatu pembunuhan, penganiayaan atau suatu perbuatan yang mengabaikan seseorang sampai menyebabkan

\footnotetext{
${ }^{36}$ Made Wahyu Chandra Satriana. (2018). "Efektifitas Pengaturan Euthanasia Dalam KUHP Terhadap Pasien Penderita Kanker Dengan Kondisi Inpersistent Vegetative State," in Seminar Nasional Riset Inovatif 6.

${ }^{37}$ Suwarto. (2009). "Euthanasia Dan Perkembangannya Dalam Kitab Undang-Undang Hukum Pidana," Jurnal Hukum Pro Justitia, 27( 2): 169-176.
} 
meninggal dunia. Sesuai dengan tanggungjawabnya, para dokter dan tenaga medis akan selalu berusaha secara maksimal agar dapat menyembuhkan penyakit yang diderita pasien. Namun perlu diingat bahwa dokter tidak akan mengobati penyakit yang tidak dapat disembuhkan. ${ }^{38}$

Munculnya permintaan tindakan medis untuk mengakhiri kehidupan pada akhir akhir ini seperti pada kasus Hasan Kesuma yang mengajukan suntik mati untuk istrinya, Ny. Again dan terakhir kasus Rudi Hartono yang mengajukan hal yang sama untuk istrinya, Ny. Siti Zuleha, maka perlunya dicermati secara hukum. Kedua kasus ini secara konseptual dikualifikasi sebagai non-voluntary eutanasia, tetapi secara yuridis formal (meninjau KUHP) kasus ini tidak bisa dikualifikasikan sebagai eutanasia sebagaimana yang tertera dalam Pasal 344 KUHP. $^{39}$ Secara yuridis formal kasus tersebut paling memungkinkan untuk disebut sebagai pembunuhan biasa sebagaimana dimaksud Pasal 338 KUHP yang secara tegas menyatakan "Barang siapa sengaja merampas nyawa orang lain diancam, karena pembunuhan dengan pidana penjara paling lama lima belas tahun", atau pembunuhan berencana sebagaimana dalam Pasal 340 KUHP yang menyatakan "Barang siapa dengan sengaja dan dengan rencana lebih dulu merampas nyawa orang lain diancam, karena pembunuhan berencana, dengan pidana mati atau pidana penjara seumur hidup atau selama waktu tertentu paling lama dua puluh tahun". 40

Seperti yang telah diketahui bahwa eutanasia merupakan perbuatan yang dilarang dan dapat menimbulkan ancaman pidana seperti yang diatur pada Pasal 344 KUHP, namun kenyataannya pencantuman pasal ini dirasa kurang efisien sebab sulitnya pembuktian. Untuk mengatasi hal tersebut, maka Leenen melalui Supriati Tjahjaningtyas, menanyakan kepada pembuat undang - undang agar ketentuan yang terdapat pada Pasal 344 KUHP ditambahkan dengan ayat-ayat yang memuat ketentuan tentang : ${ }^{41}$ (1) Pengecualian penjatuhan pidana terhadap eutanasia seorang pasien, bila dilakukan oleh seorang dokter yang mengobatinya; (2) Beberapa keharusan mengenai prosedur seperti pernyataan pasien secara tertulis dan konsultasi dokter lain.

\footnotetext{
${ }^{38}$ Made Wahyu Chandra Satriana, loc.cit.

${ }^{39}$ Muh Amiruddin. (2017). "Perbandingan Pelaksanaan Euthanasia Di Negara Yang Menganut Sistem Hukum Eropa Kontinental Dan Sistem Hukum Anglo Saxon,” Jurnal Jursprudencie, 4(1): 83-102.

${ }^{40}$ Hermien Hardiati Koeswadji. (1998). Hukum Kedokteran. Studi Tentang Hubungan Hukum Dalam Mana Dokter Sebagai Salah Satu Pihak. Jakarta: PT. Aditya Bakti.

${ }^{41}$ Leenen, "Rechten van Morsen Inde Gezcnheidszorg" on Supriati Tjahjaningtyas (1986). Euthanasia Ditinjau Dari Hukum Pidana Yang Berlaku Di Indonesia.
} 
Leenen melalui usulannya apabila diterima, maka tidak dapat dipungkiri akan berakibat terhadap sesuatu yang lebih penting dan lebih luas serta prinsipal jangkauannya, yaitu kemungkinan adanya pengakuan terhadap hak manusia untuk menentukan nasib sendiri (the right for self determination).

Dilihat dari segi hukum jelaslah bahwa pengaturan eutanasia yang lengkap sampai saat ini belum ada, padahal masalah eutanasia ini menyangkut nyawa manusia dan kasus-kasusnya mulai semakin bermunculan. Untuk itu penanggulangan masalah eutanasia, perlu diatur aturan khusus sehingga tidak bertentangan dengan hukum, moral dan agama. Perlunya menserasikan masalah eutanasia dengan hukum, dimaksudkan agar eutanasia tidak merupakan suatu hal yang dilematis bagi dokter. Menurut hemat penulis, agar eutanasia diperoleh dasar tindakan medis untuk kesejahteraan umat manusia. Perlunya aturan pelegalan eutanasia didasarkan pada berkembang luasnya pokok-pokok pikiran baru yang muncul yakni: ${ }^{42}$ Pertama, bahwa orang mempunyai hak untuk menentukan dirinya sendiri dalam arti the right to self determination. Kedua, bahwa orang bukan mempunyai hak untuk mati, melainkan hak untuk hidup dan mati (the right choose beetwen life and death) dalam arti jika seseorang mempunyai hak untuk hidup, maka sama juga mempunyai hak untuk menentukan akhir kehidupannya. Ketiga, bahwa manusia tidak boleh dipaksa untuk menderita yang tidak dapat ditanggungnya dalam arti sama dengan penganiayaan (many individual today are afraid of protected dying and dependence. It would be logical for the society to permit the termination of useless torture). Keempat, bahwa eutanasia merupakan tindakan untuk mengakhiri hidup seseorang atas permintaan orang yang bersangkutan karena penyakit yang dideritanya (eutanasia is the act of putting to death painlessly a person suffering froman incruable disease). Kelima, bahwa sudah semakin dipahami tentang definisi hidup mati dan kesehatan tidak statis (the definition of life, death, and healty are moving).

Meninjau perkembangan ilmu hukum setelah tahun 1987, muncul pemikiran baru tentang eutanasia sebagai standart pengakuan hukum yang bersifat komplementer, yaitu: ${ }^{43}$

a. Dapat melepaskan dari tuntutan hukum apabila dokter telah menjalankan tugas sesuai dengan etika medis dan bertindak secara profesional medis.

\footnotetext{
${ }^{42}$ Khoiruddin Manahan. (2018). "Euthanasia Dalam Perspektif Hukum Positif Dan Politik Hukum Pidana Di Indonesia," Usu Law Journal, 6(3): 110-118.

${ }^{43}$ Ibid.
} 
b. Dapat melepaskan diri dari tuntutan hukum apabila dalam bentuk pseudo eutanasia, dalam arti: (1) Mengakhiri perawatan pasien karena gejala mati batang otak; (2) Mengakhiri hidup seseorang dalam keadaan darurat (emergency); (3) Memberhentikan perawatan medis yang tidak berguna lagi dan dokter menolak perawatan medis berupa auto eutanasia mengingat tanpa ijin pasien dokter tidak diperkenankan melakukan tindakan medis karena bertentangan dengan asas keperdataan.

Perkembangan pokok-pokok pikiran tentang eutanasia yang menjadi ukuran medis normatif di atas dapat dijadikan ukuran medis normatif dalam perkembangan penegakan hukum khususnya eutanasia di Indonesia. Perlunya perkembangan hukum ini mengingat perubahan nilai yang kerap terjadi di masyarakat dan sifat hukum yang dinamis sehingga menjadikan legalisasi eutanasia dalam pembaharuan rumusan hukum pidana di Indonesia sebagai sesuatu yang memiliki potensial nyata.

\section{2) Pelaksanaan Euthanasia di Beberapa Negara}

\section{a. Belanda}

Belanda telah melegalkan eutanasia melalui hukum positifnya yang diatur dalam wet van 12 April 2001 Wet toetsing levensbeeindiging op verzoek en hulp bij zelfdoding atau Undang - Undang mengenai Pengakhiran Kehidupan atas Permintaan dan Bunuh Diri Terbantu (The Termination of Life on Request and Assisted Suicide) dan mulai berlaku pada 1 April 2002. ${ }^{44}$ Belanda menjadi paradigma utama eutanasia dalam praktik di dunia saat ini. Asosiasi Medis Belanda adalah satu - satunya di dunia yang menerima bahwa praktik medis terdiri dari penyembuhan dan peningkatan kesehatan, tetapi juga membantu pasien mencapai kematian yang damai dan bermartabat.

Eutanasia atau bunuh diri dengan bantuan tidak dianggap sebagai pelanggaran jika kondisi tertentu terpenuhi. Penting untuk dicatat bahwa eutanasia dan bunuh diri dengan bantuan masih dianggap sebagai tindak pidana sebagaimana yang tertera pada Articles 293 dan 294 Criminal Code. ${ }^{45}$ Sebagai konsekuensi dari amandemen oleh peraturan ini, maka dokter yang bertanggung jawab tidak dituntut jika dia telah mengamati secara cermat kriteria yang terdapat pada Section 2 of the Act dan melaporkan intervensinya ke ahli patologi. Kriterianya adalah sebagai berikut: ${ }^{46}$

\footnotetext{
${ }^{44}$ Nuno Ferreira, loc.cit.

${ }^{45}$ Rospita A. Siregar. (2015). "Euthanasia Dan Hak Asasi Manusia,” Jurnal Hukum to-ra, 1(3): 193-200.

${ }^{46}$ Nuno Ferreira, loc.cit.
} 
Pertama, Ada permintaan eutanasia secara sukarela, pertimbangan dengan baik, adanya kemauan yang kuat, dan eksplisit (pembuatan permintaan tertulis yang diantisipasi dari pasien yang berusia setidaknya enam belas tahun); Kedua, Dokter memberitahu pasien tentang situasi yang terjadi dan prospek yang akan terjadi; Menurut pendapat medis yang berlaku, penderitaan pasien tidak tertahankan dan tidak ada prospek perbaikan; Ketiga, Dokter dan pasien mendiskusikan alternatif untuk eutanasia dan telah sepakat bahwa tidak ada solusi lain yang dapat diperkirakan; Keempat, Dokter berkonsultasi dengan setidaknya satu dokter lain dengan sudut pandang independen, yang pasti pernah melihat pasien dan memberikan pendapat tertulis tentang kriteria perawatan; Kelima, Eutanasia dilakukan sesuai dengan praktik kedokteran yang baik.

Seperti yang telah disebutkan, dokter melaporkan kepada ahli patologi tentang eutanasia yang telah dipraktikkan. Laporan ini sangat rinci dan harus memberikan jawaban yang lengkap untuk semua aspek penting terkait penyakit, alasan permintaan untuk eutanasia, hasil konsultasi dengan dokter / dokter lain dan pelaksanaan eutanasia itu sendiri. Selanjutnya, ahli patologi melaporkan kasus kepada komite peninjau regional, yang menilai apakah dokter yang merawat bertindak sesuai dengan kriteria perawatan. Jika memenuhi kriteria tersebut, maka laporan tersebut akan disimpan dalam arsip, jika tidak panitia menyerahkan ketidaksesuainnya kepada Kejaksaan, yang akan memutuskan apakah akan melakukan penuntutan atau tidak. Apabila seorang dokter tidak taat pada kriteria yang ditetapkan dalam undang-undang, maka dapat dihukum penjara selama 12 tahun, tergantung pada verifikasi. ${ }^{47}$

Alasan yang paling relevan Belanda memimpin dalam menetapkan aturan progresif tentang eutanasia karena berkaitan dengan ciri - ciri agama dan sosial Belanda dimana tradisi toleransi agama dan moral telah berkontribusi pada masyarakat yang demokratis dan permisif. Orang - orang dianggap sangat mandiri, menghargai integritas moral dan adanya semangat membela kebebasan warga sipil. Selain itu, peran dokter keluaraga dan karakteristik sistem hukum juga menambah kekuatan legalisasi eutanasia. ${ }^{48}$

\footnotetext{
47 Ibid.

48 Ibid.
} 


\section{b. Belgia}

Penahanan dan pencabutan pengobatan telah lama diterima secara umum di Belgia. Selain itu, dukungan populer untuk eutanasia mencapai $72 \%$ dari populasi pada tahun $2001 .^{49}$ Proses legalisasi eutanasia memakan waktu total tiga tahun dan dianggap menghasilkan rezim yang lebih ketat daripada rezim Belanda. Undang undang Belgia yang melegalkan eutanasia yaitu Act of 28 May 2002 on Eutanasia baru efektif berjalan pada tanggal 20 September 2002. Adapun persyaratan pelaksanaan eutanasia berdasarkan Article 3 adalah sebagai berikut :

1. Usia atau pasien minor yang dibebaskan, tetapi minimal berumur 15 tahun;

2. Penderitaan fisik atau mental yang terus - menerus dan tak tertahanlam dan tidak dapat diredakan;

3. Adanya sesuatu akibat dari gangguan yang tidak disengaja atau patologis;

4. Kondisi serius dan tidak dapat disembuhkan;

5. Adanya verifikasi kapasitas dokter untuk menyatakan permintaan, usia dan kesadaran pasien;

6. Permintaan harus sukarela, diulang dan dipertimbangkan dengan hati - hati, serta bukan karena tekanan dari luar;

7. Permintaan harus ditulis, diberi tanggal dan ditandatangani, dapat dibuat pada saat itu sendiri atau sebelumnya (masa berlaku terbatas hingga 5 tahun) dan dapat dicabut atau diubah kapan saja;

8. Wawancara antara dokter dan pasien dimana dokter menginformasikan pasien tentang pilihan terapi yang mungkin masih tersedia dan mengadakan wawancara berkala untuk memastikan bahwa pasien secara fisik atau psikis terus menerus menderita dan mengulangi permintaannya.

Belgia sendiri mempunyai Komisi Federal yang bertugas mengontro; dan mengevaluasi penerapan undang-undang. Semua dokumen pasien yang telah menerima eutanasia, dengan menyebutkan persyaratan tindakan dan prosedur apa saja yang telah dilakukan dikirimkan ke Komisi Federal. Kemudian, komisi ini memverifikasi apakah prosedur yang telah dilakukan sesuai dengan aturan yang berlaku. Apabila ada pelanggaran, Komisi ini meneruskan berkas tersebut ke Kejaksaan dan kasus tersebut akan ditangani sesuai dengan ketentuan umum hukum pidana yang berlaku. Menurut hal ini, perawat medis professional yang

\footnotetext{
${ }^{49}$ Ibid.
} 
bertanggungjawab dapat dituntut dengan pembunuhan sukarela, pembunuhan berencana atau pembunuhan beracun seperti yang terdapat dalam Articles 393, 394, and 397 Penal Code. Komisi ini juga bertugas untuk menyampaikan kepada DPR laporan - laporan yang menjelaskan dan mengevaluasi penerapan undang - undang ini, serta memberikan rekomendasi untuk perubahan atau penambahan undang undang bila diperlukan.

\section{c. Luxembourg}

Pada 16 Maret 2009, eutanasia dan bunuh diri dengan bantuan disahkan di Luksemburg, dan saat ini diatur oleh Comissão Nacional de Controle e Avaliação (Komisi Nasional untuk Pengendalian dan Penilaian) ${ }^{50}$. Undang-undang tersebut mencakup orang dewasa yang kompeten, orang dengan penyakit yang tidak dapat disembuhkan dan mematikan yang menyebabkan penderitaan fisik atau psikologis yang terus-menerus dan tak tertahankan, tanpa kemungkinan pemulihan. Pasien harus meminta prosedur melalui "ketentuan akhir hidupnya", yang merupakan dokumen tertulis yang wajib didaftarkan dan dianalisis oleh Komisi Nasional untuk Pengendalian dan Penilaian (Comissão Nacional de Controle e Avaliação).

Dokumen tersebut juga memungkinkan pasien untuk mencatat keadaan di mana dia ingin menjalani kematian bantuan, yang dilakukan oleh dokter yang dipercaya oleh pemohon. Permintaan dapat dicabut oleh pasien setiap saat, dan dalam hal ini akan dihapus dari rekam medis. Sebelum prosedur, dokter harus berkonsultasi dengan ahli independen lain, tim kesehatan pasien, dan "orang terpercaya" yang ditunjuk oleh pasien; setelah selesai, kematian harus dilaporkan ke Komisi dalam waktu delapan hari. Menurut laporan terakhir Komisi, antara 2009 dan 2014, 34 kasus kematian yang dibantu telah terdaftar. Dari jumlah tersebut, 21 adalah perempuan, sebagian besar berusia antara 60 dan 79; 27 menderita kanker dan 22 menjalani prosedur di rumah sakit. $^{51}$

\footnotetext{
${ }^{50}$ Mariana Parreiras Reis de Castro, et.al. (2016). "Euthanasia and Assisted Suicide in Western Countries: A Systematic Review," The Revista Bioetica Research 24,(2).

${ }^{51}$ Ibid.
} 


\section{Penutup}

Hak untuk hidup yang tidak boleh dicabut secara semena-mena atau "arbitrarily deprived" yang dilaksanakan dengan membatasi cakupan dari hak tersebut, dan oleh karena itu merupakan tugas negara untuk memastikan hak untuk hidup. Negara yang memperbolehkan euthanasia harus menyediakan prosedur keselamatan yang efektif supaya tidak digunakan sebagai penyalahgunaan.

Hadirnya eutanasia dianggap sebagai hak asasi manusia berupa hak untuk mati yang dianggap dapat mendatangkan kebahagiaan dan menyenangkan bagi dirinya. Hak untuk menentukan nasib sendiri merupakan bagian dari Hak Asasi Manusia, pada hakekatnya hak ini menjadi bagian bagi hak-hak dasar tertentu, termasuk dalam hal ini hak dari pasien untuk menentukan pilihannya dalam hal pelayanan kesehatannya.

Dalam hukum positif di Indonesia tidak dimungkinkan melakukan pegakhiran hidup seseorag karena dalam pasal Pasal 344 KUHP secara tegas menyatakan : "Barang siapa merampas nyawa orang lain atas permintaan itu sendiri yang jelas dinyatakan dengan kesungguhan hati diancam dengan pidana penjara paling lama dua belas tahun". Terdapat ketentuan lain yang digunakan untuk menjerat pelaku euthanasia yaitu Pasal 304 KUHP yang menegaskan "Barang siapa dengan sengaja menempatkan atau membiarkan seorang dalam keadaan sengsara, padahal menurut hukum yang berlaku baginya atau karena persetujuan, dia wajib memberikan kehidupan, perawatan, atau pemeliharaan kepada orang itu, diancam dengan pidana penjara paling lama dua tahun delapan bulan atau denda paling banyak tiga ratus rupiah". Pasal 304 KUHP ini memberikan penegasan bahwa dalam konteks peraturan perundang-undangan, meninggalkan orang yang membutuhkan pertolongan juga dikualifikasi tindak pidana. Di sisi lain, terdapat beberapa Negara yang sudah melegalkan eutanasia diantaranya adalah Belanda, Belgia, Luxembourg. 


\section{Referensi}

Amiruddin, M. (2017). Perbandingan Pelaksanaan Euthanasia Di Negara Yang Menganut Sistem Hukum Eropa Kontinental Dan Sistem Hukum Anglo Saxon. Jurnal Jurisprudence, 83-102.

Baker, P. (2016). Human Rights and the Law. Australian Human Rights Commission, 6(3).

Bhavya, A. R. (2019). Euthanasia: An Indian Perspective. ZENITH International Journal of Multidisciplinary Research, 9(6), 367-373.

Debora, Y. (2017). Permintaan Suntik Mati Yang Kotroversial, https://tirto.id/permintaansuntik-mati-yang-kontroversial-cokd, diakses pada 13 November 2020.

Dworkin, R. (2000). Sovereign Virtue The Theory and Practice of Equality. Cambridge, Massachusetts: Harvard University Press.

Faiz, P. M. (2015). Pendekatan MK Terhadap Konstitusionalitas Hukuman Mati. Majalah Konstitusi No. 96.

Ferreira, N. (2005). Revisiting Euthanasia: A Comparative Analysis of a Right to Die in Dignity. SSRN Electronic Journal, 4(8), 1-66.

Halim, A. (2012). Euthanasia Dalam Perspektif Moral Dan Hukum. Jurnal Pemikiran Hukum Al-Mazaib, 1(4), 1-13.

Hayati, N. (2004). Euthanasia Dalam Perspektif Hak Asasi Manusia Dan Kaitannya Dengan Hukum Pidana. Lex Jurnalica, 1(2), 90-99.

Koeswadji, H. H. (1998). Huum Kedokteran Studi Tentang Hubungan Hukum Dalam Mana Dokter Sebagai Salah Satu Pihak. Jakarta: PT. Aditya Bakti.

Leenen, "Rechten van Morsen Inde Gezcnheidszorg" on Supriati Tjahjaningtyas (1986). Euthanasia Ditinjau Dari Hukum Pidana Yang Berlaku Di Indonesia. Surabaya: Universitas Airlangga

Mahmudi, S. S. (1986). Penelitian Hukum Normatif Suatu Tinjauan Singkat. Jakarta: PT. Grafindo Persada.

Manahan, K. (2018). Euthanasia Dalam Perspektif Hukum Positif Dan Politik Hukum Pidana Di Indonesia. USU Law Jornal, 6(3), 110-118.

Mariana Parreiras Reis de Castro, e. (2016). Euthanasia and Assisted Suicide in Western Countries: A Systematic Review. The Revista Bioetica Research 24,(2).

Marzuki, P. M. (2005). Penelitian Hukum. Jakarta: Kencana Prenada Media Group.

Natasha, C. (1996). Euthanasia- the Australian Law in an International Context Part I: Passive Voluntary Euthanasia Research Paper. 
Nugraha, X. (2020). Analisis Penerapan Asas Safety Beyond Economic Reason Dalam Putusan Mahkamah Konstitusi Nomor 41/PUU-XVI/2018. Humani (Hukum dan Masyarakat Madani), 216-228.

Nugraha, X. R. I. (2019). Rekonstruksi Batas Usia Minimal Perkawinan Sebagai Bentuk Perlindungan Hukum. Lex Scientia Law Review, 3(1), 40-54.

Nowak, M. (2005). U.N. Covenant on Civil and Political Rights : CCPR Commentary / Manfred Nowak. . Germany: Arlington.

Nurmawati, N. G. (2019). Tinjauan Yuridis Euthanasia Ditinjau Dari Aspek Hukum Pidana. Jurnal Kertha Wicara, 8(10), 1-13.

Paulus, P. K. (2013). Kajian Euthanasia Menurut HAM (Studi Banding Hukum Nasional Belanda). Jurnal Hukum Unsrat, 21(3): 117-139

Pradjonggo, T. S. (2016). Suntik Mati (Euthanasia) Ditinjau Dari Aspek Hukum Pidana Dan Hak Asasi Manusia Di Indonesia. Jurnal Ilmiah Pendidikan Pancasila dan Kewaganegaraa, 1(1), 56-63.

Satriana, M. W. (2018). Efektifitas Pengaturan Euthanasia Dalam KUHP Terhadap Pasien Penderita Kanker Dengan Kondisi Inpersistent Vegetative State. Seminar Nasional Riset novatif 6.

Siregar, R. A. (2015). Euthanasia Dan Hak Asasi Manusia. Jurnal Hukum to-ra, 1(3), 193200.

Suwarto. (2009). Euthanasia Dan Perkembangannya Dalam Kitab Undang - Undang Hukum Pidana. Jurnal Hukum Pro Justitia, 27(2), 169-176.

Ven, J. A. (2010). Human Rights or Religious Rules?. . Leiden, Boston: Brill.

Zaccaria, H.-G. Z. (2019). Euthanasia, Abortion, Death Penalty and Religion: The Right to Life and Its Limitations: International Empirical Research. Switzerland: Springer Nature Switzerland AG.

Zdenkowski, G. (2015). Human Rights and Euthanasia. Deutsches Zentralblatt fur Krankenpflege 11(1). 